\title{
Compliance with International Financial Reporting Standards by Listed Companies in Ghana
}

\author{
Edward Marfo Yiadom ${ }^{1} \&$ Wisdom Atsunyo ${ }^{2}$ \\ ${ }^{1}$ Department of Accounting and Finance, University of Cape Coast, Ghana \\ ${ }^{2}$ Centre for Continuing Education, University of Cape Coast, Ghana \\ Correspondence: Wisdom Atsunyo, Centre for Continuing Education, University of Cape Coast, Ghana. E-mail: \\ wisdom.atsunyo@ucc.edu.gh
}

Received: May 12, 2014

Accepted: August 19, 2014

Online Published: September 25, 2014

doi:10.5539/ijbm.v9n10p87

URL: http://dx.doi.org/10.5539/ijbm.v9n10p87

\begin{abstract}
This study examined the extent to which companies listed on the Ghana Stock Exchange (GSE) comply with International Financial Reporting Standards' (IFRSs) presentation and disclosure requirement. With the aid of a checklist, an index of compliance was devised to quantify the level of compliance. This was applied to the 2010 financial statement of 31 companies listed on the GSE. Descriptive statistics was used to analyse the extent of compliance by companies categorised in line with industry classification of the GSE. The study further examined relationships between company attributes and the extent of compliance. In addition, factors influencing the extent of IFRSs compliance are revealed using correlation and multiple regression analysis. ANOVA was employed to explore statistically significant differences between industry types with regards to their extent of compliance.

The findings revealed an overall mean compliance of $85.8 \%$ in Ghana. Company attributes of size, profitability, auditor type, internationality and industry type associate positively with IFRSs compliance. ANOVA results revealed differences between industry types with regards to their compliance rate.

The study recommends that the Institute of Chartered Accountants Ghana liaise with regulators to organise regular training programmes for companies to provide a practical guide for full compliance since the IFRSs receive continuous amendment.
\end{abstract}

Keywords: compliance, financial reporting standards, public companies

\section{Introduction}

The fact that users rely on financial statements, especially financial reports from public companies, for economic decisions has called for the establishment of standards to regulate the preparation of such statements to enhance their reliability. Accounting standards have been developed by different countries to regulate the accounting systems peculiar to their environment. Overtime, businesses have grown and expanded across borders. The capital needs of companies have also grown with new capital secured from international markets. Different information needs of users from both domestic and international sources emerged and difficulties of financial statements comparability as a result of different standards also emerged. Due to increasing integration of international markets, companies around the world are in need of executing their business in a manner to conform to international corporate activities (Beier, 2008). Thus, Tafara (2008) was right in noting that the stakeholders and investors are no longer limited in their selection of companies and investment opportunities to search for the best portfolio.

According to Choi and Meek (2005), a higher level of comparability and quality of financial statements is required because of an increased international audience and their unfamiliarity with different national domestic accounting standards that the financial statements are produced under. If the investors and stakeholders are not able to obtain an adequate and transparent view on the selected companies, extra costs in the form of lost potential capital or investment opportunities will occur as a result of lack of confidence in the companies.

As the forces of globalization prompt more countries to open their doors to foreign investment and as businesses expand across borders, both public and private sector entities are increasingly acknowledging the benefits of having a uniform financial reporting framework supported by strong globally accepted accounting standards. 
Attempts toward harmonisation led to the establishment of the International Accounting Standards Committee (IASC) in 1973 which released a series of standards called the International Accounting Standards (IAS). From April 2001, the International Accounting Standard Board (IASB) assumed accounting standard setting responsibilities from its predecessor body IASC with the authority of making the established standards mandatory among all it members. The IASB adopted the body of standards issued by IASC which will continue to be designated 'IAS' however any new standards would be published in series called the International Financial Reporting Standards (IFRS). The long awaited globally accepted accounting Standard has become a success with the development of IFRS by IASB with over 120 countries converging their standards into IFRS (Institute of Chartered Accountants England and Wales, 2010).

On $1^{\text {st }}$ January 2007, Ghana, in her efforts to promote accelerated growth of the economy through private sector-led growth, adopted IFRS in place of its out-dated Ghana National Accounting standards (GNAS). The council of the Institute of Chartered Accountants, Ghana (ICAG), formally launched the adoption on $23^{\text {rd }}$ January, 2007 and required all listed companies, public entities, banks, and insurance companies to comply with the IFRS as at $31^{\text {st }}$ December, 2007 and other entities were given an additional transition period of two years to comply (United Nations, 2007). At present Ghana is among fifteen countries in Africa with the likes of Botswana, Egypt, Ethiopia, Kenya, Lesotho, Malawi, Mauritius, Mozambique, Namibia, Sierra Leone, South Africa, Tanzania, Zimbabwe, Swaziland and Uganda to have adopted or converged to IFRS (Zori, 2011; PricewaterhouseCoopers, 2010).

However, empirical studies by Street and Gray (2001) and Glaum and Street (2003) revealed that companies have frequently claimed in annual reports that they are in full compliance with IFRS, while in reality there are significant deviations from IFRS. Similarly, the International Federation of Accountants (IFAC) has noted auditors confirmation of firms compliance with IASs when the accounting policies and notes indicate contrary (Cairns, 1997). It is against this background that the study sought to inquire the extent of compliance with IFRS by all companies listed on the Ghana Stock Exchange (GSE) and to determine the factors influencing IFRSs compliance as well as differences, if any, between types of industry with regard to their compliance with IFRSs.

The rest of this paper is organised as follows: section 2 discusses related literature and development of hypothesis; section 3 presents research methodology; section 4 discuses the empirical results and section 5 summarises and concludes the entire study.

\section{Review of Related Literature and Development of Hypothesis}

\subsection{IFRSs Compliance}

A number of studies have been conducted in the area of IFRSs compliance. Among these studies, a number have reported cases of significant non-compliance. Street and Gray (2000a,); Street and Bryant (2000); Tower, Hancock and Taplin (1999); Street, Gray and Bryant (1999); and Cairns (1999a) provided the initial evidence of significant non-compliance among companies purporting to use IAS. Street et al. (1999) studied compliance with the ten IASs issued as part of the IASCs comparability project. Using a survey instrument based on the text in the ten revised IASs, the authors inspected the 1996 annual report of 49 large companies that claimed to comply with IAS in their accounting policy notes. They found that non-compliance was common when the sample companies presented an extraordinary item, the revaluation of property plant and equipment, pension disclosures, the valuation of inventories, the restatement of foreign entities for companies operating in hyperinflationary economies and the amortisation of goodwill.

Street and Gray (2001) used the financial statements of two hundred and seventy nine companies appearing on the 1999 IASC list of companies referring to their use of IAS and found that there was significant non-compliance with IAS requirements. Street and Gray found that, among other things, compliance tends to be greatest for companies domiciled in China and most problematic for companies domiciled in France.

Using a sample of twenty two companies listed on the Kuwait Stock Exchange, Albdelrahim, Hewaidy, and Mostafa (1997) examined companies' compliance with mandatory IAS requirements in 1995 financial statements. The study investigated three IAS that relate to fixed assets: IAS 16, IAS 20, and IAS 23. The data required for the study was obtained from a questionnaire and interviews with financial managers and accountants. The findings of the study show that companies fully complied with some requirements but not with other requirements. They stressed the importance of further training for accountants who are responsible for applying IAS in Kuwaiti companies to promote compliance.

Tower et al. (1999) undertook an empirical study of listed companies' compliance with IASs in Asia-Pacific countries. They measured compliance with IAS by extensive analysis of 1997 annual reports selected randomly 
from each of Australia, Hong Kong, Malaysia, Philippines, Singapore and Thailand. The twenty-six IAS standards applicable to 1997 fiscal year ends were examined. Each annual report was carefully examined for compliance with IASC rules. Tower et al coded compliance into seven categories as compared to the eleven categories used by Cairns (1999a). Tower et al. (1999) computed two compliance ratios. Ratio 1, with non-disclosure indicating "non-applicability" of particular accounting issues and ratio 2 with non-disclosure indicating "non-compliance" with IAS guidelines. The authors found that, ratio one revealed overall high mean of $90.68 \%$ compliance and stricter ratio two however revealed a much lower overall mean of $42.2 \%$. Their study also revealed high compliance in Australia (94\%) and Thailand (93\%) as compared to Singapore (90\%), Malaysia (90\%), Philippines (88\%), and Hong Kong (88\%). Tower reported an adjusted $\mathrm{R}^{2}$ of 0.224 for company attributes influencing IFRS compliance level.

Ballas and Tzovas (2010) have further affirmed significant non-compliance by examining the extent to which Greek firms comply with the disclosure requirements of IFRS. Financial statements of 32 Greek firms were examined for compliance. Disclosure compliance of a company was depicted as the value of a compliance ratio computed for each company. The compliance ratio was computed as what a company disclosed in its report to what it is obliged to disclose for each category. The study revealed that no single firm fully complied with disclosure requirements while the average compliance rate was $62.9 \%$. The study also revealed that the level of compliance was positively related with company attributes such as listing status, size, and profitability while a negative relationship was established for sector classification.

Mutawaa and Hawaidy (2010) empirically investigate the extent of compliance of Kuwaiti listed companies (KSE) with IFRSs disclosure requirements. They further examined the factors associated with the level of compliance. The 2006 annual report of 48 non-financial companies were randomly sampled from 121 Kuwaiti companies listed on KSE and carefully scrutinized for compliance with IFRSs disclosure compliance. Standards examined were IAS 1, 10, 14, 16, 18, 21, 23, 24, 27, 28, 32 and 34. Mutawaa and Hawaidy measured compliance with a self-developed checklist based on IASB required disclosures and reference to checklist used in prior research as well as checklist published by Deloitte and KPMG. The study revealed an overall average compliance rate of $70 \%$. IAS 18 was reported as the standard with the highest mean compliance score of $95 \%$. $79.3 \%$ was reported as the highest overall compliance scored by an industry (investment companies) with $96.7 \%$ and $64 \%$ being the maximum and minimum within the industry, respectively.

Al-Shammari (2011) extends the study of IFRS compliance by investigating the extent to which 168 companies listed on KSE comply with the disclosure requirements of IFRSs. The annual reports of 2008 were examined using a self constructed checklist based on 21 selected standards. Disclosure index was computed consistent with prior research (Mutawaa \& Hawaidy, 2010; Ballas \& Tzovas, 2010) by dividing the total number of disclosure provided in company's annual reports by the total applicable score. The study of Al-Shammari (2011) revealed compliance mean of $82 \%$ which was lower than that observed in developed countries such as Australia $94 \%$ (Tower et al. 1999), and Germany $81 \%$ (Glaum \& Street, 2003). The study therefore concluded that incentives for compliance are less in Kuwait than developed countries. The study further determined whether certain company attributes influence compliance level among companies. The study revealed that size, auditor type, liquidity, industry type, and internationality influenced the level of compliance among firms. Al-Shammari reported an adjusted $\mathrm{R}^{2}$ of 0.407 .

\subsection{Company Attributes Influencing IFRSs Compliance}

Significant number of studies has been conducted into firms' characteristics and how they influence the extent to which companies comply with the disclosure requirements of IASs now IFRSs (Belkaoui \& Kahl, 1978; Cooke, 1989; Tower et al, 1999; Street \& Bryant, 2000; Glaum \& Street, 2003; Al-Shammari, 2011). The features of a firm that affect its compliance rate include: size, profitability, auditor type, internationality, leverage, and industry type.

\subsubsection{Corporate Size}

According to Cooke (1989), the size of a firm irrespective of the way it is measured (e.g., total assets, sales turnover, and number of shares) is a variable that can explain to a reasonable extent, the quality of firms disclosures. According to Ahmed and Nicholas (1994) and Jones and Higgins, (2006), larger companies are anticipated to possess the resources that are necessary for the preparation of an event such as the introduction of IFRS. However, empirical studies found mixed results with the relationship between the extent of compliance with IFRS and company size. Tower et al (1999); Street and Bryant (2000); Street and Gray (2001) and Glaum and Street (2003) found no evidence of an association between company size and the level of voluntary compliance with IASs. Nevertheless Joshi and Al-Mudhahki (2001); Ali, Ahmed, and Henry (2004); Ballas and 
Tzovas (2010) and Al-Shammari (2011) found a significant positive relationship between corporate size and level of compliance. It is therefore hypothesised that:

H1a: The size of listed companies as measured by book value of equity has statistically significant positive relationship with the rate of IFRSs compliance.

H1b: The size of listed companies as measured by total assets has statistically significant positive relationship with the rate of IFRSs compliance.

\subsubsection{Profitability}

Inchausti (1997); Owusu-Ansah (1998), and Palmer (2008) posit that the compliance of a firm to the disclosure requirements prescribed by particular accounting standards is affected by the profitability of the firm. Wagenhofer (1990) also argued that the less profitable firms might increase the level of disclosure in order to explain to the market the reasons for the decline in their profitability. However, empirical evidence is mixed. Inchausti (1997); Dumontier and Raffournier (1998); Street and Bryant (2000); Street and Gray (2001) and Glaum and Street (2003) do not provide evidence consistent with this conclusion. Patten and Zelenka (1997) and Owusu-Ansah (1998) reported a significant positive relationship between profitability and extent of IFRS compliance. The study therefore tests the hypothesis that:

H2a: Companies profitability as measured by return on equity has a significant positive relationship with the rate of IFRSs compliance.

H2b: Companies profitability as measured by return on assets has a significant positive relationship with the rate of IFRSs compliance.

\subsubsection{Type of Auditor}

Watts and Zimmerman (1983) and Craswell and Taylor (1992) put forward the view that choice of external auditor is a mechanism that helps alleviate conflicts of interest between managers and shareholders. Jensen and Meckling (1976) and Watts and Zimmerman (1983) also argued that large audit firms act as a mechanism to reduce agency costs and exert more of a monitoring role by limiting opportunistic behaviour by managers. A significant number of empirical studies yielded consistent results with regard to the relationship between the type of auditor and compliance with IFRSs.

Street and Gray (2001) reported that the level of compliance with IAS disclosure and measurement requirements was positively associated with companies in developed countries being audited by "Big Five" auditing firms. Glaum and Street (2003) also found a positive association between the level of mandatory compliance with IASs disclosure requirements and companies being audited by "Big Five" auditing firms in Germany. Wallace and Naser (1995) found that the extent of compliance with mandatory disclosure was negatively associated with companies being audited by one of the "Big Six" in Hong Kong, while Patton and ZeleNka (1997) found a positive association in the Czech Republic. Al-Shammari (2011) also reported a positive association in Kuwait. It is therefore hypothesised that:

H3: There is significant positive relationship between auditor type and rate of IFRSs compliance.

\subsubsection{Internationality}

Malone, Fries, and Jones (1993) argued that companies with international activities are more likely to be subjected to a broader range of regulatory authorities and to have diverse financiers, suppliers and customers. Consequently they are more likely to disclose more detailed information and to do so in a more widely understood form. Glaum and Street (2003) found a positive association in Germany and Al-Shammari (2011) found a positive association in Kuwait. The study therefore tests the hypothesis that:

H4: Companies with multinational affiliations have higher level of compliance with IFRSs disclosure requirement.

\subsubsection{Industry Type}

Ferguson, Lam and Lee (2002), suggested that companies in identifiable, highly competitive industries might disclose less information to prevent loss from the leakage of proprietary information. Malone et al. (1993) and Wallace, Naser, and Mora (1994) also argued that the adoption of industry related practices may lead to varied levels of disclosure on similar items in financial reports of companies in different industries. However, prior research provides conflicting results as to the association between type of industry and level of disclosure. While Wallace et al. (1994), Owusu-Ansah (1998), Street and Bryant (2000), Glaum and Street (2003) found no evidence of an association between industry type and level of disclosure, Wallace and Naser (1995); Street and 
Gray (2001); Naser, Al-Khatib and Karbhari (2002), reported a positive association between type of industry and level of disclosure. It is therefore hypothesised that:

H5: Type of industry has statistically significant positive relationship with rate of IFRSs compliance.

\subsubsection{Leverage}

Leverage has been suggested as relevant explaining variation in the extent of disclosure compliance. Jensen and Meckling (1976) and Fama and Jensen (1983) suggested agency conflicts between principals (debt holders in this case) and their agents (managers acting in the interests of shareholders) give rise to agency costs. Agency costs of this type are expected to be higher for companies with higher leverage because there is relatively more wealth for managers to transfer from debt holders. As such, companies with higher leverage can be expected to disclose more information to reduce agency costs by reassuring debt holders that their interests are protected. Prior research has provided conflicting association between leverage and level of disclosure. While Tower et al. (1999); Wallace and Naser (1995); Ahmed and Nicholls (1994); and Ali et al. (2004) found no association, Belkaoui and Kahl (1978), and Al-shammari (2011) noted a positive significant association between leverage and level of disclosure. The study therefore tests the hypothesis that:

H6: Companies leverage has statistically significant positive relationship with the rate of IFRSs compliance.

\section{Methodology}

\subsection{Population and Data Source}

The population of the study was companies listed on the Ghana Stock Exchange as at $31^{\text {st }}$ December 2010 whose financial reports claim compliance in accordance with IFRS. The choice of listed companies was informed by the fact that IFRS is primarily developed for use by publicly listed companies (Holt, 2010). As at $31^{\text {st }}$ December, 2010, thirty-three companies were listed on Ghana Stock Exchange. However, two companies were excluded from the population because their accounts did not claim compliance with IFRS making them irrelevant for inclusion in the study. In effect, thirty-one companies were of interest and relevance to the study. The population was fully covered in the study because of its small size and secondly the researcher sought to determine the holistic compliance rate of companies listed on the GSE.

Data for the study was obtained from the 2010 annual financial reports of companies listed on the GSE. A compliance checklist was developed and applied to each annual report to check compliance. The compliance checklist was designed for each of the six selected IFRSs (IAS 1, IAS 7, IAS 12, IAS 16, IAS 18 and IAS 19). The checklist was developed with reference to IFRSs issued by the IASB, checklist used in prior research (Street et al, 1999; Street\& Gray 2002) and disclosure and presentation checklist published by Deloitte (2010). The validity and comprehensiveness of the checklist was confirmed by two experienced chartered accountants. Prior to checking compliance, each annual report was thoroughly read and consolidated by logical reasoning to determine applicability to each of the checklist items. This prevented a company from being penalised for not disclosing an item deemed irrelevant to its operations. For scoring, each disclosure item ticked under category "a" (Yes) on the checklist was given a score of one and a zero score for category "b" (No) and "C" (NA). This approach is consistent with prior research by Ballas and Tzovas (2010).

\subsection{Measurement of Dependent Variable}

The dependant variable in this research was IFRS compliance. The level of IFRS compliance was measured by a self-constructed compliance index (CINDEX) consistent with prior compliance studies such as (Tower et al. 1999; Street \& Bryant, 2000; Street \& Gray, 2001; Glaum \& Street, 2003; and Ballas \& Tzovas, 2010). The presentation and disclosure compliance of a company is depicted as the value of a compliance index that is computed for each company. The compliance index is the ratio of what a company presented and disclosed in its annual report to what it is obliged to present and disclose for each category of standard. Thus, the compliance ratio is computed by dividing the total of (Yes) over the total applicable presentation and disclosure requirements.

\subsection{Measurement of Independent Variables}

\subsubsection{Company Size}

The book value of equity and that of total assets was used to measure company size. This has been used in some prior studies (e.g. Tower et al., 1999; Ballas \& Tzovas, 2010).

\subsubsection{Profitability}

Profitability was measured by ratio of return on equity (ROE), and accounting profit. This has been used in 
previous studies like Wallace et al., 1994; and Street \& Bryant (2000).

\subsubsection{Auditor Type}

Auditor type was measured by a dummy variable coded 'one' if the company was audited by one of the big four audit firms (PricewaterhouseCoopers, Deloitte \& Touche, Ernst \& Young, and KPMG) and 'zero' for those otherwise. This measure is consistent with prior studies by Wallace and Naser (1995) and Owusu-Ansah and Yeoh (2005).

\subsubsection{Internationality}

Internationality was measured by a dummy variable coded 'one' if the company has affiliation as a subsidiary of a parent company in any of the developed countries. This measure is consistent with prior research (Craig and Diga 1998; Chau and Cray 2002).

\subsubsection{Industry Type}

Industry was measured by a set of dummy variables coded 'one' for finance and insurance, 'two' for paper converters and information technology, 'three' for agric and agro-processing mining, 'four' for pharmaceutical and beverages, 'five' for manufacturing and trading, and 'six' for metal and oil. This measure is consistent with prior research (Tower et al., 1999; Al-Shammari, 2005).

\subsubsection{Leverage}

Leverage was measured by debt to equity ratio. This is consistent with prior research (Mutawaa \& Hewaidy, 2010).

\subsection{Data Analysis}

Descriptive statistics were used to analyse the extent of compliance with IFRSs. One-way analysis of variance (ANOVA) was used to determine whether statistical difference exist among industries with regards to rate of compliance. The six research hypotheses were tested using Pearson Product Moment correlation. Multiple regression analysis was further used to explore the influence of the independent variables on the dependent variable.

\section{Results and Discussion}

\subsection{Descriptive Statistics}

Table 1. Descriptive statistics for industry type and their respective compliance score

\begin{tabular}{lccccc}
\hline Types of Industry & N & Min. & Max. & Mean & SD \\
\hline Finance and Insurance & 11 & 0.734 & 0.951 & 0.842 & 0.068 \\
Paper Converters/IT & 5 & 0.622 & 0.862 & 0.763 & 0.118 \\
Agric/Agro Processing & 4 & 0.741 & 0.924 & 0.839 & 0.075 \\
Pharmaceutical/Beverages & 4 & 0.827 & 0.966 & 0.913 & 0.063 \\
Manufacturing and Trading & 4 & 0.865 & 0.968 & 0.927 & 0.044 \\
Metals/Oil & 3 & 0.902 & 0.994 & 0.941 & 0.047 \\
Overall Compliance (CINDEX) & 31 & 0.622 & 0.994 & 0.858 & 0.090 \\
\hline
\end{tabular}

Source: Field Data, 2012.

Table 1 shows the overall IFRSs compliance rate of companies listed on the GSE with regards to the selected standards. Table 1 indicates that the overall mean compliance score for all companies listed on the GSE in 2010 financial year was $85.8 \%$. The maximum compliance score by a company was $99.4 \%$ and a minimum compliance score of $62.2 \%$. The results clearly shows that no company listed on the GSE fully obtained an overall compliance rate of $100 \%$ with all the IFRS required presentation and disclosures in line with (Tower et al. 1999; Street \& Bryant, 2000; Glaum \& Street, 2003; Ballas \& Tzovas, 2010; Al-Shammari, 2011). Interestingly, no qualified audit opinion regarding non-compliance with required presentation and disclosure was issued despite significant non-compliance by companies. It was also interesting to note that all companies claim that their accounts are prepared fully in line with IFRSs.

Table 1 further shows the overall compliance rate with the six selected IFRSs for each industry. Results indicated 
in Table 1 shows that metal and oil industry scored the highest mean compliance of $94.1 \%$ with $99.4 \%$ and $90.2 \%$ being the maximum and minimum compliance, respectively, within the industry while the least overall compliance mean score of $76.3 \%$ was obtained for paper converters and information technology industry which has a maximum score of $86.2 \%$ and minimum score of $62.2 \%$.

Table 2. Descriptive statistics for compliance index for each IFRS

\begin{tabular}{lllll}
\hline International Financial Reporting Standards & Min. & Max. & Mean & SD \\
\hline IAS 1: Presentation of Financial Statements & 0.558 & 0.961 & 0.809 & 0.094 \\
IAS 7: Statement of Cash Flows & 0.778 & 1.000 & 0.986 & 0.047 \\
IAS 16: Property, Plant and Equipment & 0.462 & 1.000 & 0.859 & 0.179 \\
IAS 18: Revenues & 1.000 & 1.000 & 1.000 & 0.000 \\
IAS 19: Employee Benefits & 0.000 & 1.000 & 0.671 & 0.356 \\
IAS 12: Income Taxes & 0.000 & 1.000 & 0.827 & 0.208 \\
\hline
\end{tabular}

Source: Field Data, 2012.

Table 2 presents descriptive statistics for compliance index (CINDEX) by accounting standards. The presentation and disclosure score of the 31 companies listed on the Ghana Stock Exchange with regards to the six selected IFRSs are described by the calculation of the arithmetic means for each. The minimum and the maximum represent the case of one company with respect to each standard, while the mean represent the extent of all the thirty-one companies' compliance with each IFRs presentation and disclosure requirements

Table 2 indicates that IAS 18 had an absolute compliance of $100 \%$ by companies listed on the GSE. The highest mean score recorded for IAS 18 was 1.000 with a standard deviation of 0.000 , which implies that there was no variability in compliance among listed companies with regards to IAS 18 there by showing a $100 \%$ for both maximum and minimum compliance score among companies. This finding is in line with empirical results by Mutawaa and Hewaidy (2010) who reported IAS 18 as the standard with the highest mean compliance score. The checklist from which the compliance scores were derived reveals IAS 18 as the standard with the least presentation and disclosure requirement among the selected standards which might account for its absolute compliance.

The next highest complied standard is IAS 7 with a mean compliance score of $98.6 \%$; followed by IAS 16 with a mean compliance of $85.9 \%$; IAS 12 follows with a mean score of $82.7 \%$. IAS 1, which has the highest presentation and disclosure requirement, had a mean compliance score of $80.9 \%$. IAS 19 was the standard with the least mean compliance score of $67.1 \%$, which is in line with Street et al. (1999) who found IAS 19 as being problematic for companies to comply with.

Table 3. Descriptive statistics for other explanatory variables

\begin{tabular}{lllll}
\hline Variables & Min. & Max. & Mean & SD \\
\hline Size $\quad$ & & & \\
$\quad$ Book value of equity $(\mathrm{GH} \ell) \mathrm{m}$ & -0.677250 & 27023 & 967 & 4840 \\
$\quad$ Total assets $(\mathrm{GH} \phi) \mathrm{m}$ & 0.953588 & 62629 & 2750 & 11280 \\
Profitability & & & \\
$\quad$ Return on equity & -80.700 & 1.170 & -3.253 & 15.227 \\
$\quad$ Return on total assets & -0.597 & 0.342 & 0.025 & 0.153 \\
Type of auditor & 0.000 & 1.000 & 0.742 & 0.445 \\
Internationality & 0.000 & 1.000 & 0.355 & 0.486 \\
Leverage & 0.000 & 4.400 & 0.855 & 1.225
\end{tabular}

Source: Field Data, 2012.

Table 3 shows a brief statistical description of the explanatory or independent variables. Company size measured 
by book value of equity ranged from -0.66725 to 27023 million Ghana cedis with an average size of 967 million Ghana cedis. Company size measured by total assets ranged from 0.953588 to 62629 million Ghana cedis with an average of 2750 million Ghana cedis. The mean of company size in terms of book value of equity and total assets were 967 and 2750 millions of Ghana cedis respectively. This size distribution was, as usual, moved the normality of the distribution to skewedness. This skewedness was mitigated by utilising the natural logarithm of size (book value of equity and total assets) in the regression analysis and testing of the first hypothesis that is consistent with prior studies (Cooke, 1992; Wallace et al., 1994; Al-Shammari, 2011).

Profitability was measured by return on equity and return on total assets. Surprisingly, average percentage profit was negative $325 \%$ (reflecting high negative return on equity) as measured by return on equity. However profitability as measured by return on total assets gave a more positive picture with an average of percentage profit of $2.5 \%$ and ranged from negative $59.7 \%$ to $34.2 \%$. Table 5 also shows that more than half of the listed companies representing $74.2 \%$ of the sample population are audited by one of the big four audit firms which are Pricewaterhouse Coopers, Deloitte and Touche, Ernst and Young, and KPMG while 25.8\% of the population are audited by local audit firms. Only $36 \%$ of the sample companies had affiliation as subsidiary of a parent company in any of the developed countries. Average leverage of the sample companies is $86 \%$ measured by debt to equity indicating that the sample companies are on average heavily leveraged.

\subsection{ANOVA Results}

Table 4. Multiple comparisons of types of industry by IFRSs compliance ratio

\begin{tabular}{|c|c|c|c|c|c|}
\hline $\begin{array}{l}\text { Types of } \\
\text { Industry (I) }\end{array}$ & Types of Industry (J) & $\begin{array}{l}\text { Mean } \\
\text { Difference } \\
(\mathrm{I}-\mathrm{J})\end{array}$ & $\begin{array}{l}\text { Std. } \\
\text { Error }\end{array}$ & $\mathrm{F}$ & $\begin{array}{l}\text { Eta } \\
\text { Square }\end{array}$ \\
\hline \multirow[t]{5}{*}{ Finance / Insurance } & Paper Converters / IT & 0.0791 & 0.040 & $3.600^{*}$ & 0.417 \\
\hline & Agric/Agro Processing & 0.003 & 0.044 & & \\
\hline & Pharmaceutical/Beverages & -0.071 & 0.044 & & \\
\hline & Manufacturing and Trading & -.084712 & 0.044 & & \\
\hline & Metals/Oil & -0.099 & 0.049 & & \\
\hline \multirow[t]{5}{*}{ Paper Converters / IT } & Finance and Insurance & -0.079 & 0.040 & & \\
\hline & Agric/Agro Processing & -0.076 & 0.050 & & \\
\hline & Pharmaceutical/Beverages & -0.150 & 0.050 & & \\
\hline & Manufacturing and Trading & $-0.164^{*}$ & 0.050 & & \\
\hline & Metals/Oil & $-0.178^{*}$ & 0.055 & & \\
\hline \multirow[t]{5}{*}{ Agric / Agro Processing } & Finance and Insurance & -0.003 & 0.044 & & \\
\hline & Paper Converters/IT & 0.076 & 0.050 & & \\
\hline & Pharmaceutical/Beverages & -0.074 & 0.053 & & \\
\hline & Manufacturing and Trading & -0.088 & 0.053 & & \\
\hline & Metals / Oil & -0.102 & 0.057 & & \\
\hline \multirow{5}{*}{$\begin{array}{l}\text { Pharmaceutical/ } \\
\text { Beverages }\end{array}$} & Finance and Insurance & 0.071 & 0.044 & & \\
\hline & Paper Converters / IT & 0.150 & 0.050 & & \\
\hline & Agric / Agro Processing & 0.074 & 0.053 & & \\
\hline & Manufacturing and Trading & -0.013 & 0.053 & & \\
\hline & Metals / Oil & -0.028 & 0.057 & & \\
\hline \multirow{4}{*}{$\begin{array}{l}\text { Manufacturing } \\
\text { Trading }\end{array}$} & Finance and Insurance & 0.085 & 0.043 & & \\
\hline & Paper Converters / IT & $0.164 *$ & 0.050 & & \\
\hline & Agric / Agro Processing & 0.088 & 0.053 & & \\
\hline & Pharmaceutical / Beverages & 0.013 & 0.053 & & \\
\hline
\end{tabular}




\begin{tabular}{llll}
\hline & Metals / Oil & -0.014 & 0.057 \\
& Finance and Insurance & 0.099 & 0.049 \\
& Paper Converters / IT & $0.178^{*}$ & 0.055 \\
Metals / Oil & Agric / Agro Processing & 0.102 & 0.057 \\
& Pharmaceutical / Beverages & 0.028 & 0.057 \\
& Manufacturing and Trading & 0.014 & 0.057 \\
\hline
\end{tabular}

Note. $* \overline{\mathrm{P}<0.05}$;

Source: Field Data, 2012.

A one-way analysis of variance was conducted to explore differences among industries with regard to their rate of compliance with the IFRSs disclosure requirements as shown in Table 4. The listed sample companies were divided into six types or groups (Group 1: finance and insurance; Group 2: paper converters/ information technology; Group 3: agric/agro processing; Group 4: pharmaceutical/beverages; Group 5: manufacturing and trading; Group 6: metals/oil). There was a statistically significant difference at the $\mathrm{p}<0.05$ level in the compliance rate of IFRSs disclosure requirements for the six groups or types of industries $[F(5,25)=3.600, p<$ 0.014]. Using Cohen (1988) guidelines on the interpretation of Eta Square, the actual difference in the mean scores between the groups or types of industry was large (42\%). The effect size calculated using eta square, is 0.417. Post - hoc comparisons using the Turkey HSD test, as shown in Table 4, indicated that the mean score for the paper converters and information technology industry $(\mathrm{M}=0.763, \mathrm{SD}=0.118)$ is statistically significantly different from manufacturing and trading industry $(\mathrm{M}=0.927, \mathrm{SD}=0.044)$ and metals and oil industry $(\mathrm{M}=$ $0.941, \mathrm{SD}=0.047$ ). Meaning, manufacturing and trading industry and metals and oil industry complied with the IFRSs disclosure requirements significantly more than paper converters and information technology industry.

\subsection{Correlation Analysis}

Table 5. Coefficients of correlation among level of compliance with IFRSs disclosure requirements and company attributes

\begin{tabular}{lllll}
\hline Company Attributes & Mean & SD & IFRSs Compliance Rate & Sig. \\
\hline Company size & & & & $.448^{*}$ \\
Book value of equity & 7.347 & 1.210 & & .011 \\
Profitability & & & $.225^{*}$ & .022 \\
Return on equity & -3.253 & 15.227 & $.454^{*}$ & .011 \\
Type of auditor & .742 & .445 & $.185^{*}$ & .016 \\
Internationality & .355 & .486 & $.495^{* *}$ & .005 \\
Types of industry & 2.806 & 1.778 & -.290 & .113 \\
Leverage & .855 & 1.225 & &
\end{tabular}

Source: Field Data, 2012.

Pearson Product Moment correlation was used to test the relationship between the dependent and independent variables. Table 5 presents the relevant Pearson Product Moment correlation coefficients. The following values of correlation interpretations suggested by Cohen (1988) were used as guidelines for the interpretation of the correlations.

$$
\begin{aligned}
& r=0.10 \text { to } 0.29 \text { or }-0.10 \text { to }-0.29 \\
& r=0.30 \text { to } 0.49 \text { or }-0.30 \text { to }-0.49 \\
& r=0.50 \text { to } 1.0 \text { or }-0.50 \text { to }-1.0 \\
& r=1.0 \text { or }-1.0 \\
& r=0.0
\end{aligned}
$$

weak
moderate
strong
perfect
zero

Table 5 indicates that company size as measured in terms of book value of equity and total assets are positively related to the level of company compliance with IFRSs presentation and disclosure requirements but only that of 
book value of equity was statistically significant at a significant level of 0.05 . That of total assets was non-statistically significant. Meaning, there was a moderate relationship between company size as measured in terms of book value of equity and the level of compliance with the IFRSs disclosure requirements $(r=.448, p=$ 011). This result accepts hypothesis H1a congruent with the results reported by prior researchers (e.g. Dumontier \& Raffournier, 1998; Jones \& Higgins, 2006; and Lang \& Lundholm, 1993). The results however reject hypothesis $\mathrm{H} 1 \mathrm{~b}$ that company size as measured by total assets has statistically positive relationship with the rate of IFRS compliance.

From Table 5, the relevant Pearson Product Moment correlation coefficient between profitability as measured by ROE is positively associated with the level of compliance with IFRSs disclosure requirements $(r=.225, p$ $=.022$ ). However, this is statistically significant with a weak correlation. In the case of ROA, there is a statistically significant positive weak relationship between profit and the level of company compliance with the IFRSs disclosure requirements $(\mathrm{r}=.120, \mathrm{p}=.019)$. Therefore, the results accepts H2a and H2b congruent with Owusu-Ansah (1998) but inconsistent with Street and Gray (2001), Glaum and Street (2003) who reported no relationship between profitability and extent of IFRS compliance.

As seen in Table 5 , there is a moderate statistically significant positive relationship between the type of auditor and the level of company compliance with IFRSs disclosure requirement $(\mathrm{r}=.454, \mathrm{p}=.011)$. This means that companies audited by one of the big four audit firms (PricewaterhouseCoopers, Deloitte \& Touche, Ernst \& Young, and KPMG) have a high level of compliance with the IFRSs disclosure requirements than those that were not audited by any of the big four firms. Therefore, the results accepts hypothesis 3 in line with Batton and Zolenka (1997) who reported positive association in Czech Republic but inconsistent with Wallace and Naser (1995) who found negative association in Hong Kong.

The results in Table 5, indicates that there is a weak statistically significant positive relationship between internationality and the level of company compliance with IFRSs disclosure requirement $(\mathrm{r}=.485, \mathrm{p}=.006)$. Meaning companies that are affiliated as subsidiary of a parent company in any of the developed countries have relatively higher level of compliance with the IFRSs disclosure requirements. Therefore, the results accepts hypothesis 4 in line with findings of prior research by Glaum and Street (2003) and Al-Shammari (2011) who found a weak positive association in Germany and Kuwait respectively.

Table 5 indicates that there is a strong statistically significant positive relationship between the types of industry and the level of company compliance with IFRSs disclosure requirement $(r=.495, \mathrm{p}=.005)$. Meaning the type of industry a company belongs, to a large extent relate to the level of compliance with the IFRSs disclosure requirements. Therefore, the results accepts hypothesis 5 that type of industry have statistically significant association with the level of compliance with IFRSs disclosure requirement. This finding confirms the findings of Naser et al. (2002), and Wallace and Naser (1995) who reported positive association between type of industry and level of disclosure.

From Table 5, it is further observed that there is a weak non-statistically significant negative relationship between leverage and the level of company compliance with IFRSs presentation and disclosure requirement. This infers that the debt to equity ratio (leverage) relate negatively to the level of compliance with the IFRSs disclosure requirements. However, the relationship is non-significant. Thus, the results fail to accept hypothesis 6, which claims that companies' leverage has statistically significant association with the level of compliance with IFRSs disclosure requirement. This findings is congruent with findings of Ahmed and Nicholas (1994) and Hassan et al., (2006) who found no association between companies leverage and rate of compliance but incongruent with Belkaoui and Kahl (1978), Robins and Austin 1986, and Al-Shammari (2011) who noted positive significant association between leverage and level of disclosure. 


\subsection{Regression Results}

Table 6. Influence of companies attributes on IFRSs compliance

\begin{tabular}{lllll}
\hline Company Attributes & Beta & Std. Error & t-value & p-value \\
\hline Book value of equity (Size) & -.252 & .048 & -.387 & .702 \\
Total assets (Size) & .444 & .043 & .799 & .433 \\
Return on equity (Profitability) & $.459^{*}$ & .002 & 2.579 & .029 \\
Return on total assets (Profitability) & $-.463^{* *}$ & .078 & -3.498 & .002 \\
Type of auditor & $.406^{*}$ & .033 & 2.520 & .019 \\
Internationality & .176 & .027 & 1.191 & .247 \\
Types of industry & $.538^{* *}$ & .007 & 3.641 & .001 \\
Leverage & .006 & .012 & .033 & .974 \\
\hline Constant & .590 & & & \\
R & .840 & & & \\
R Square & .706 & & & \\
Adjusted R Square & .599 & & & \\
\hline
\end{tabular}

Dependent variable: IFRSs Compliance ratio ${ }^{*} \mathrm{p}<0.01 ;{ }^{*} \mathrm{p}<0.05$.

Source: Field Data, 2012.

A multiple regression is used to examine the influence certain selected company attributes have on the level of a company's compliance with IFRSs disclosure requirements. This analysis is undertaken to better understand the individual contribution of the selected company attributes to the level of company's compliance with IFRSs disclosure requirements. The summary of the result analysis is shown in Table 6.

Table 6 indicates that among the selected company attributes used for the study, profitability as measured by both return on equity and return on total assets, types of auditor, and types of industry are the only statistically significant attributes with regard to company's level of compliance with IFRSs disclosure requirements. The company attributes that influence or predict companies level of compliance with IFRSs disclosure requirements in order of importance are types of industry $(\beta=.538(.007), p=.001)$, profitability as measured by return on equity $(\beta=.459(.002), \mathrm{p}=.029)$, type of auditor $(\beta=.406(.033), \mathrm{p}=.019)$ and profitability as measured by return on total assets $(\beta=-.463(.078), \mathrm{p}=.002)$. Among the statistically significant contributing attributes, type of industry is the most statistically significant company attribute that influences or contributes to company's level of compliance with IFRSs presentation and disclosure requirements in Ghana.

It is however significant to observe that the proportional contribution $\left(\mathrm{R}^{2}\right)$ of all the attributes of the listed sample companies to the company's compliance level with IFRSs disclosure requirements is .706 with an adjusted $\mathrm{R}^{2}$ of .599. This means that the selected company attributes (independent variables) are able to influence, predict, or explain about 60 per cent of the variance in the level of company's compliance with IFRSs disclosure and presentation requirements.

\section{Conclusion and Recommendation}

The study revealed an overall mean compliance rate of $85.8 \%$ with $62.2 \%$ and $85.8 \%$ being the minimum and maximum scored by a company. Company attributes of profitability, auditor type and industry type were found as variables influencing IFRSs compliance explaining $59.9 \%$ of variables influencing IFRSs compliance rate. The study further revealed significant differences among industries with regards to their compliance rate.

Based on the findings, the study recommended that the Institute of Chartered Accountants Ghana (ICAG), which is the sole regulator of accounting profession in Ghana, should organise regular training programmes to provide practical guide to companies for full compliance.

The study further recommended that the Ghana Companies Code 1963, (Act 179) as well as the Security and Exchange Commission Regulation 2003 which regulate financial reporting of companies in Ghana should be amended in light of the adoption of IFRSs. This would legally strengthen enforcement bodies to monitor compliance and activate penalties as set out in the law to motivate full compliance.

\section{References}

Ahmed, K., \& Nicholas, D. (1994). The impact of non-financial company characteristics on mandatory disclosure compliance in developing countries: The case of Bangladesh. International Journal of Accounting, 3(1), 
183-203.

Albdelrahim, A., Hewaidy, A., \& Mostafa, G. (1997). The relevance of IAS to the evaluation of fixed assets in Kuwait corporations. Arab Journal of Administrative Sciences, 5(1), 35-96.

Ali, M., Ahmed, K., \& Henry, D. (2004). Disclosure compliance with national accounting standards by listed companies in South Asia. Accounting and Business Research, 34(3), 183-199. http://dx.doi.org/10.1080/00014788.2004.9729963

Al-Shammari, B. (2011). Factors influencing the extent of mandatory compliance with international financial reporting standards: the case of Kuwaiti listed companies. Journal of International Business and Economics, $11(4), 305-360$.

Ballas, A. A., \& Tzovas, C. (2010). An empirical investigation of Greek firms' compliance with IFRS disclosure requirements. International Journal of Managerial and Financial Accounting, 2(1), 40-62. http://dx.doi.org/10.1504/IJMFA.2010.032489

Beier, R. J. (2008). One global flavor: Thinking about international financial reporting standards and how leading US companies are getting ready for them. Retrieved May 3, 2011, from http://www.pwc.com/extweb/home.nsf/docid/0428f13968

Belkaoui, A., \& Kahl, A. (1978). Corporate financial disclosure in Canada. Research Monograph, 1. Vancouver: Canadian Certified General Accontants Association.

Cairns, D. (1997). International Federation of Accountants: 20 years on. World Accounting Report (October).

Cairns, D. (1999). The international accounting standards survey 1999: An assessment of the use of IASS by companies, national standard setting bodies, regulators and stock exchanges. London: LLP Professional Publishing.

Chau, G. K., \& Gray, S. J. (2002). Ownership structure and corporate voluntary disclosure in Hong Kong and $\begin{array}{lllll}\text { Singapore. International Journal of accounting, } & 37(2),\end{array}$ http://dx.doi.org/10.1016/S0020-7063(02)00153-X

Choi, F. D. S., \& Meek, G. K. (2005). International Accounting (5th ed.). New Jersey: Prentice-Hall.

Cohen, J. (1988). Statistical power analysis for the behavioural sciences. New Jersey: Erlbaum.

Cooke, T. E. (1989). Voluntary corporate disclosure by Swedish companies. Journal of International Financial Management and Accounting, 1(2), 171-195. http://dx.doi.org/10.1111/j.1467-646X.1989.tb00009.x

Craig, R., \& Diga, J. (1998). Corporate accounting disclosure in ASEAN. Journal of International Financial Management and Accounting, 9(3), 246. http://dx.doi.org/10.1111/1467-646X.00039

Craswell, A. T., \& Taylor, S. L. (1992). Discretionary disclosure of reserve by oil and gas companies. Journal of Business Finance and Accounting, 19(2), 295-308. http://dx.doi.org/10.1111/j.1468-5957.1992.tb00626.x

Deloitte. (2010). IFRS presentation and disclosure checklist. Retrieved from http://www.iasplus.com/en/publications/global/models-checklist/2010/ifrs-presentation-anddisclosure-check list-2010

Dumontier, P., \& Raffournier, B. (1998). Why firms comply voluntarily with IAS: An empirical analysis with Swiss data. Journal of International Financial Management and Accounting, 9(3), 216-245. http://dx.doi.org/10.1111/1467-646X.00038

Fama, E. F., \& Jensen, M. C. (1983). Separation of ownership and control. Journal of Law and Economics, 25(June), 301-325. http://dx.doi.org/10.1086/467037

Ferguson, M. J., Lam, K. C., \& Lee G. M. (2002). Voluntary disclosure by state-owned enterprises listed on the stock exchange of Hong Kong. Journal of International Financial Management and Accounting, 13(2), 125-152. http://dx.doi.org/10.1111/1467-646X.00081

Glaum, M., \& Street, D. L. (2003). Compliance with disclosure requirements of Germany's New Market: IAS versus US GAAP. Journal of International Financial Management and Accounting, 14(1), 64-100. http://dx.doi.org/10.1111/1467-646X.00090

Holt, G. (2010). IFRS for SMEs. Retrieved June 5, 2011, from http://www.accaglobal.com

Inchausti, B. G. (1997). The influence of company characteristics and accounting regulation on information disclosed by Spanish firms. European Accounting Review, 6(1), 45-68. 
http://dx.doi.org/10.1080/096381897336863

Institute of Chartered Accountants England and Wales. (2010). Knowledge guide to international accounting standards. $\quad$ Retrieved $\quad$ November $\quad 18, \quad 2010, \quad$ from http://www.icaew.com/en/library/subject-gateways/accounting-standards/knowledge-guide-to-internationalaccounting-standards

Jensen, M., \& Meckling, W. (1976). Theory of the firm: managerial behaviour, agency costs and ownership. Journal of Financial Economics, 3(3), 305-360. http://dx.doi.org/10.1016/0304-405X(76)90026-X

Jones, S., \& Hiiggins, A. D. (2006). Australia's switch to international financial reporting standards: a perspective from account preparers. Accounting and Finance, 46, 629-652. http://dx.doi.org/10.1111/j.1467-629X.2006.00186.x

Joshi, L., \& Al-Mudhahki, J. (2001). Empirical study of compliance with international accounting standards (IAS1) by stock exchange listed companies in Bahrain. Journal of Financial Management and Analysis, 14(2), $43-54$.

Malone, D., Fries, C., \& Jones, T. (1993). An empirical investigation of the extent of corporate financial disclosure in the oil and gas industry. Journal of Accounting, Auditing and Finance, 8(3), 249-273.

Mutawaa, A. A., \& Hawaidy, A. M. (2010). Disclosure level and compliance with IFRSs: An empirical investigation of Kuwaiti companies. International Business and Economics Research Journal, 9(5), 33-50.

Naser, K., Al-Khatib, K., \& Karbhari, Y. (2002). Empirical evidence on the depth of corporate information disclosure in developing countries: The case of Jordan. Advances in international Accounting, 13, 99-118.

Owusu-Ansah, S., \& Yeoh, J. (2005). The effect of legislation on corporate disclosure practices. Abacus, 41(1), 92-109. http://dx.doi.org/10.1111/j.1467-6281.2005.00171.x

Owusu-Ansah, S. (1998). The impact of corporate attributes on the extent of mandatory disclosure and reporting by listed companies in Zimbabwe. International Journal of Accounting, 33(5), 605-631. http://dx.doi.org/10.1016/S0020-7063(98)90015-2

Palmer, P. (2008). Disclosure of the impacts of abandoning Australian equivalents of international financial reporting standards. Journal of Accounting and Finance, 48(5), 847-870.

Patton, J., \& Zelenka, I. (1997). An empirical analysis of the determinants of the extent of disclosure in annual reports of joint stock companies in the Czech Republic. European Accounting Review, 6(4), 605-626. http://dx.doi.org/10.1080/09638189700000003

Price Water House Coopers. (2010). International financial reporting standards adoption by country. Retrieved October 8, 2010, from www.pwc.com/us/en/issues/ifrs-reporting/assets/ifrs-country-adoption

Street, D., \& Gray, S. (2001). Observance of international accounting standards: factors explaining non-compliance by companies referring to the use of IAS. An ACCA Research Monograph, 74.

Street, D., Gray, S., \& Bryant, S. (1999). Acceptance and observance of international accounting standards: An empirical study of companies claiming to comply with IASs. International Journal of Accounting, 34(1), 11-48. http://dx.doi.org/10.1016/S0020-7063(99)80002-8

Street, D., \& Bryant, S. (2000). Disclosure level and compliance with IASs: A comparison of companies with and without U.S. listings and filings. International Journal of Accounting, 35(3), 305-329. http://dx.doi.org/10.1016/S0020-7063(00)00060-1

Tafara, E. (2008). Speech by SEC staff: Investors' choice in the regulation of global capital markets? Retrieved May 3, 2011, from http://www.sec.gov/news/speech/2008/spchhtm

Tower, G., Hancock, P., \& Taplin, R. (1999). A regional study of listed companies' compliance with international accounting standards. Accounting Forum, 3(3), 293-305. http://dx.doi.org/10.1016/S0020-7063(99)80002-8

United Nations. (2007). International accounting and reporting issues by centre on transnational corporations, united nations. Retrieved January 23, 2012, from http://books.google.com.ca/books/about/international-accounting-and-reporting-1.html?id=uekqii6yjmq\&hl

Wagenhofer, A. (1990). The demand for disclosure and actual disclosure by firms. Paper presented at the XIII EAA Congress, Budapest.

Wallace, R. S. O., \& Naser, K. (1995). Firm-specific determinants of the comprehensiveness of mandatory disclosure in the corporate annual reports of firms listed on the stock exchange of Hong Kong. Journal of 
Accounting and Public Policy, 14(4), 311-368. http://dx.doi.org/10.1016/0278-4254(95)00042-9

Wallace, R. S. O., Naser, K., \& Mora, A. (1994). The relationship between the comprehensiveness of corporate annual reports and firm characteristics in Spain. Accounting and Business Research, 25(97), 41-53. http://dx.doi.org/10.1080/00014788.1994.9729927

Watts, R., \& Zimmerman, J. (1983). Agency problems, auditing and theory of the firm: Some evidence. Journal of Law and Economics, 1226, 613-633. http://dx.doi.org/10.1086/467051

Zori, S. (2011). International Financial reporting standards in the African continent: a look at Ghana. Retrieved January 23, 2012 , from http://solomonzori.blogspot.com/2011/08/ifrs-in-african-continent-look-at-ghana.html

\section{Copyrights}

Copyright for this article is retained by the author(s), with first publication rights granted to the journal.

This is an open-access article distributed under the terms and conditions of the Creative Commons Attribution license (http://creativecommons.org/licenses/by/3.0/). 